\title{
Demythologising social cohesion: Towards a practical theological vision
}

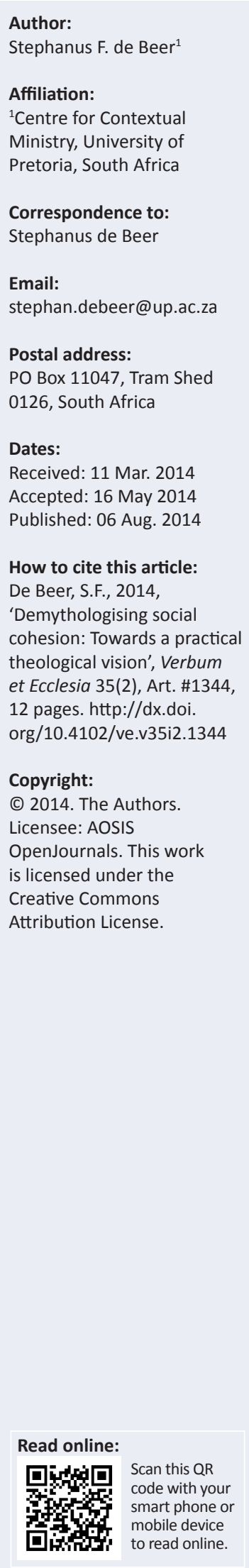

This article considers the topical issue of social cohesion. It seeks to demythologise the issue bringing it into critical conversation with eight related categories. It proposes that a vision of a socially cohesive society should employ all eight categories as parallel and complementary strategies. Secondly, it proposes a practical theological vision of social cohesion that will not only embrace these eight categories but will root itself in a spirituality of the table, informed by a vision of the oikos of God, seeking shalom in the oikos and doing so through four strategic moments of engagement.

Intradisciplinary and/or interdisciplinary implications: This article indicates that social cohesion requires an integrated approach of different strategies, not competing but complementing each other. Social cohesion requires interdisciplinary, intradisciplinary and transdisciplinary research and action. For example, exploring ways in which land redistribution inhibits or contributes to social cohesion requires multiple stakeholders and disciplines discerning together. The proposed practical theological vision implies new categories to be included in curricula and practical theological discourse for it to contribute meaningfully not only to the current debate but also to practices fostering a socially cohesive society.

\section{Introduction}

There has been a growing body of knowledge on the subject of social cohesion, not without criticism. Some, rather cynically, regard social cohesion as just another buzzword, thrown around glibly by different people as the latest fad. It could indeed be viewed as an ambiguous, even elusive, term, presenting different and even competing visions and connotations at times. It could also present itself as mere jargon without substance or a myth perpetuating itself, depending on who uses it and in which context. Bernard (1999:2) views social cohesion as '... a quasi-concept, that is, one of those hybrid mental constructions that politics proposes to us'.

Social cohesion, on the one hand, is a teleological or normative concept, an ever-suggestive goal. On the other hand, it can speak of realities already achieved that can be measured and assessed.

This article will seek to 'demythologise' or 'un-buzz' the term, bringing social cohesion into conversation with a number of other concepts. It will address, on the one hand, the question of diversity and participation, namely social capital, social inclusion, healing and reconciliation as well as citizenship and participation and, on the other hand, also the question of equity and justice, namely social justice, restitution, land distribution and spatial transformation.

The article proposes that all eight categories introduced here need to be pursued if we are to achieve the highest possible degree of social cohesion and, indeed, social cohesion that is radically inclusive of the most vulnerable members of our society. Put in theological language, all of the eight categories are needed if we are to make visible the household of God in the cities of the world or if we want to contribute to the greatest sense of shalom or wholeness in society at large and in local communities in particular.

In the second part of this article, I seek to make some tentative suggestions for a practicaltheological vision of social cohesion, rooting it in a spirituality of the table. It is informed by a vision of the oikos, or household of God or humanity, seeking shalom or wholeness in the household, doing so through four strategic moments of engagement in the household.

\section{Social cohesion: Competing visions and compelling myths}

In a meeting with the Faculty of Theology at the University of Pretoria, the Vice-Chancellor and Principal of the University, Prof Cheryl de la Rey, noted the absence of dedicated research at the University on issues related to reconciliation. This prompted Julian Müller, then professor of 
Practical Theology at the University, to conceptualise a unit for social cohesion and reconciliation. This unit was launched in August of 2013, hosted by the Centre for Contextual Ministry.

Part of the purpose of this article is to seek for clarity on what is meant by social cohesion and to start to construct the outlines of a practical-theological vision of social cohesion or a way for accompanying processes and visions of social cohesion, constructively but also critically. However, this article is also meant to honour the legacy and vision of Julian Müller, this time embodied by the newly established unit.

Social cohesion speaks of a socially cohesive society, namely a society that does not minimise the reality of diversity and complexity but that displays high degrees of collectivity, interconnectivity, interdependence, acceptance, inclusivity, equity, justice, fairness, mutuality and integration. It speaks of a society that unifies people despite their difference; that builds on local, community and regional assets; that journeys towards a common vision or visions that have been negotiated and constructed despite (initially) competing visions.

And yet, not all voices advocating for social cohesion approach this matter from the same angle. In an article on street homelessness in the United Kingdom, Fitzpatrick and Jones (2005:389) argue that government's policies prioritise 'social cohesion' over 'social justice'. They almost make these two concepts sound mutually exclusive. They derive at their conclusion based on policy content on street homelessness in the United Kingdom with a strong 'social control' emphasis, regarding homelessness as 'anti-social behaviour' instead of an effect of poverty or structural injustice. Therefore, the argument goes, 'coercion or forceful measures' seem to be favoured for enforcing social cohesion instead of measures that would facilitate higher degrees of social justice. Social cohesion envisaged in such policy should rather be viewed as social coercion, displaying a facade of societal well-being whilst deeper fractures have not sufficiently been addressed.

In the South African context, a new directorate for social cohesion was created, rather oddly located in the National Department of Arts and Culture (DAC 2012). The directorate defines social cohesion as such:

... the degree of social integration and inclusion in communities and society at large, and the extent to which mutual solidarity finds expression among individuals and communities.

In terms of this definition, a community or society is cohesive to the extent that the inequalities, exclusions and disparities based on ethnicity, gender, class, nationality, age, disability or any other distinctions which engender divisions distrust and conflict are reduced and/or eliminated in a planned and sustained manner. This, with community members and citizens as active participants, working together for the attainment of shared goals, designed and agreed upon to improve the living conditions for all. (n.p.)

Although much of the content of this definition would find resonance in subsequent paragraphs of this article, it is also ironic that, whilst this directorate is being created, the disaster at Marikana happened and 44 people died mostly striking mine workers killed by the South African police force but also a few police officers (cf. Nyar 2013). At the same time under the banner of Operation CleanUp, informal traders in Pretoria and Johannesburg were removed from the streets and prevented from trading (Maseng 2013; Makhubu 2014) and informal settlements continued to expand on the fringes of cities and towns all over the country (cf. Venter 2014).

Labonte (2004:116), in reflecting on social cohesion, cautions against 'concepts that direct us towards a wishful desire for social harmony'. Being a conflict sociologist, he is sceptical about such concepts as they usually need to practice suppression in order to be achieved. In his view, it is often in social protest and disharmony that the seeds for reform and positive change lay.

In reflecting on social cohesion, this article seeks to acknowledge competing visions and languages used to reflect on social cohesion. When the National Department of Arts and Culture speaks of social cohesion, it is not necessarily the same as when shack-dweller movements or informal traders or gay and lesbian organisations speak of it. What is more, any vision of social cohesion probably stands or falls by how well it ensures the inclusion of the most 'invisible' or most marginal or most vulnerable people of society - their presence, their voices and their full and equal participation.

\section{The impossibility or possibility of social cohesion}

In the following part of the article, I am reflecting on the impossibility or possibility of social cohesion, exploring different societal challenges that could either destroy or enhance a vision and possibilities of a socially cohesive society. Implicit in this section is the acknowledgement that social cohesion is not a concept that necessarily elicits consensus as it is contextually and ideologically determined. At the same time, it is not achieved through a cheap vision or quick projects because, at its core, if we take the question of equality and justice seriously, it requires a much more fundamental and radical restructuring of the way in which all of society is currently structured.

Different theorists define different key characteristics of social cohesion. Jenson (1998), for example, suggests five key elements: affiliation or isolation, insertion or exclusion, participation or passivity, acceptance or rejection and legitimacy or illegitimacy.

In this section, I am introducing eight concepts that are all related to social cohesion. They have the potential either to contribute to or to reduce a socially cohesive society, depending on how intentionally it is integrated as part of a more comprehensive vision and paradigm towards a socially cohesive society. 


\section{Social cohesion and social capital}

In much of the literature, a correlation is drawn between social cohesion and social capital. Some views are more positive and others more critical.

Three characteristics of social capital '... can be found in almost all the definitions: social contacts, memberships in social groups and the question of trust' (Klein 2013:896). Klein (2013:896) views social capital as functioning more at a local, relational level whilst social cohesion operates at a larger societal level and it relates to more than the sum total of social capital mobilised or leveraged between different locales.

Labonte (2004:116) has reservations about the use of concepts such as social cohesion or social capital. Social capital, in Labonte's view, often seeks to force opposing parties, political and other, into coalitions, often at the expense of the smaller party. Similarly, different institutions appropriate social cohesion for different aims. The World Bank, Labonte suggests, aspires to social cohesion as it would secure fertile soil for economic growth and 'unfettered markets to work their magic' (Labonte 2004:116). This would often not have the effect of socio-economic change at the local level but simply facilitate a widening gap between rich and poor.

Forrest and Kearns (2013:2137-2138) speak of two thrusts in the use of social capital in policy development, namely (1) in relation to social cohesion and (2) in relation to neighbourhood regeneration.

Some regard social cohesion as 'a bottom-up process founded upon local social capital, rather than as a top-down process'. Putnam (1993:35) speaks of such social capital as 'features of social organisation such as networks, norms and trust that facilitate co-ordination and co-operation for mutual benefit', fostering in return a sense of cohesion. In a later definition, Putnam (2000) speaks of social capital as the 'connections among individuals - social networks and the norms of reciprocity and trustworthiness that arise from them'.

A second thrust is the use of social capital in terms of neighbourhood regeneration. Strong social networks and social organisation in neighbourhoods are forms of social capital or local assets that support neighbourhood regeneration. A depletion of social capital is often the result of weakened social networks, community disengagement and disillusionment (Forrest \& Kearns 2013:2138-2139) that also adds to neighbourhood degeneration.

In literature on social capital, a distinction is often made between bonding capital and bridging capital (cf. Cloete \& Kotze 2009:13). Bonding capital is more internal to a community, serving as the glue that binds together local groups. It is the local social relationships, social networks and interpersonal or institutional connections. These can be very homogeneous and exclusive, and sometimes in some communities they are, but they do not have to be. Bridging capital is that which creates links between different groups or neighbourhoods to ensure deeper connectedness and to facilitate the bridging of fractures between communities. Often bridging capital is not sufficient, in other words, external connections are not optimally made, which then results in social capital not optimally contributing to a socially cohesive society. Although it facilitates greater levels of cohesion and wellbeing in the local neighbourhood, this is where it ends.

Social capital can also be 'divisive and exclusionary' (Forrest \& Kearns 2013:2141). If it is only expressed as bonding capital amongst homogeneous people such as residents of a particular tightly-knit neighbourhood or gated community, it can be used 'against' others. If the shared values of local communities do not include and practice a value of radical social inclusion, such local social capital might foster suspicion, stigmatisation or exclusion, both overtly and covertly (Forrest \& Kearns 2013:2141).

If both social capital and social cohesion are viewed critically by some and as concepts for the potential co-option of poor people and neighbourhoods in the interest of economic growth mostly benefiting the wealthy, should we even consider these terms in practical-theological language and thinking, or should they be dismissed downright?

\section{I suggest that:}

- it is our responsibility to engage these terms in order to reflect on them critically as they are widely used in societal discourses with regard to governance, developmental goals, et cetera

- it is our task as (practical) theologians not only to reflect critically on these terms but to fill them with content appropriate to the kind of societal visions that we are imagining.

If social capital and the retrieval and fostering thereof at a local level are understood as the building of a strong local asset base, locally owned but radically inclusive in nature, particularly in poorer communities, it becomes important for practising theologians not only to accompany processes of reflection and articulation about social capital but also to help identify, retrieve and accompany the development of local social capital. In addition, practising theologians could play an important role in supporting and strengthening bonding capital (internal connectedness) but also in facilitating bridging capital (external connectedness), which will enable the optimal sharing of resources, the exchange of skills and the establishment of networks, all ingredients of a more cohesive society.

\section{Social cohesion and social inclusion}

Another concept closely related to social cohesion is that of social inclusion. Lister (2000) distinguishes between those approaches to social inclusion "which privilege "social justice" and those which focus primarily on "social cohesion"'. Those approaches favouring social justice would namely place a higher emphasis on poverty as cause of exclusion and would advocate for a more fundamental redistribution 
of material resources and of power (equality) as well as equal recognition of and respect for different social groups (diversity) (Fitzpatrick \& Jones 2005:391; cf. Levitas 1998; Young 1990). Those approaches prioritising social cohesion would employ mechanisms of social control and coercion to ensure cohesion (Fitzpatrick \& Jones 2005:391; Gray 2000), often denying the rights of people and compromising their long-term well-being.

Exclusion, in practices of social control, is often seen not as systemic forces deliberately excluding people but rather as people's anti-social behaviour, thus blaming the victim or the excluded for their own exclusion.

Labonte (2004:117) suggests that social inclusion or exclusion is a dynamic and interesting concept to consider in contemplating social cohesion. It brings to the surface an 'embedded contradiction'. It raises namely the critical question of how inclusion into social relationships, responsible for excluding in the first place, should then work: Will it '... accommodate people to relative powerlessness rather than challenge the hierarchies that create it?' (Labonte 2004:117). It is about the terms of social inclusion: who is including whom and on whose terms?

Labonte (2004:118) warns against an uncritical embrace of social inclusion without sufficient appreciation for 'the use, abuse and distribution of power' that reinforces and mediates exclusion. Labonte (2004) argues:

We should not let the warmth of our inclusive ideal smother our anger over exclusivity's unfairness. Anger is often the magnet of mobilisation, and mobilisation is often the tool for social transformation that shifts power relationships in ways that allow societies to become more inclusive. (p. 118)

In line with such a critical reading of social inclusion or exclusion, Labonte goes further to suggest that exclusion is sometimes a deliberate strategy (on the part of the excluded) in response to structural or systemic relationships that are exploitative and exclusive. Instead of participating in such relationships, exclusion as deliberate strategy is practising an 'empowered act of resistance to socio-economic systems that ... continue to replicate and heighten the material hierarchies of inequality' (Labonte 2004:117).

The use of social inclusion as a concept is contextually and ideologically determined. Furthermore, Fitzpatrick and Jones (2005:390) suggest that, apart from the contested nature of the exact meaning of social exclusion in the literature, the meaning of social inclusion in response and how it is to be expressed in practice, is also rather unclear. This does not mean, however, that the concepts should immediately be discarded, but its use should rather be located in the way in which Lister does it by prioritising either social justice or social control.

If the premise is that access to income and the redistribution of resources alone will necessarily facilitate social inclusion, Labonte (2004:117) argues in conversation with other theorists that such are 'necessary but not sufficient conditions' for guaranteeing social inclusion. When social inclusion is introduced in this article, I do it in concurrence with Labonte (2004:117-118), arguing that, instead of mere 'remedial reforms' to include excluded people, what is required is indeed more fundamental systemic transformation.

Labonte's conclusion (2004:120) is that we should not be concerned with excluded groups but more with the socioeconomic conditions that caused the exclusion, as well as the social groups benefiting from the exclusion. Such an either-or approach presents a problem to me as a practical theologian. My assertion would be that we have to be concerned with the transformation of systems that exclude, even as we seek to accompany, serve and facilitate the inclusion of excluded people in our own communities whilst structural transformation is still underway.

However, further on in his conclusion Labonte (2004:120) seems to alter his strong stance slightly, explaining the subtitle of the article from which I have drawn, 'dancing the dialectic', suggesting that the 'dialectic dances between seeking to include more people into social systems stratified by exclusion even while trying to transform these systems'. It is this dance that should also be the art of the practical or practising theologian.

\section{Social cohesion, healing and reconciliation}

In August of 2013, the unit for social cohesion and reconciliation, based in the Centre for Contextual Ministry (CCM) at the University of Pretoria, hosted its first public conversation, entitled 'Rainbow: Promise or premise? A consultation on social cohesion and reconciliation' (cf. De Beer 2013a).

In conceptualising the consultation, a clear choice was made for a more narrative approach, much informed by the thinking of Julian Müller. Instead of a paper-driven consultation, which would have been the obvious route seeing it was hosted on a university campus by a centre of the University, the approach was one of in-depth conversation combined with story-telling and deep listening.

The 57 practitioners, activists and academics who gathered on 21 and 22 August 2013 sought to discern both on-going and new fractures in our South African society as well as the challenges faced by those committed to work for cohesion and reconciliation.

An assumption of this newly formed unit was probably that reconciliation, in a deep and real sense, is one of the important characteristics preceding social cohesion. Alternatively, social cohesion in its fullest sense cannot be achieved without there also being a deep sense of reconciliation across all kinds of barriers.

One of the key themes emerging on the first day of this conversation was that of our collective woundedness as a 
nation. It became clear that any dream of social cohesion is impossible without works of reconciliation that will attend very specifically to our collective woundedness. The presence of Father Michael Lapsley from the Institute for the Healing of Memories, together with his colleague, Alphonse Niyodusenga, contributed to an understanding of memory work for the healing of past and present wounds in order for people to be able to live their lives constructively into the future (Institute for the Healing of Memories 2011). When people, individually or collectively, are enslaved by 'ancient, past or recent memories', as coined by Father Lapsley (2013), or by a debilitating sense of woundedness, it is a profoundly important personal, ecclesial and public pastoral responsibility to be considered and engaged with creatively.

Since 1994, the face of South Africa changed, and reconciliation, although still very much addressing issues of race against the backdrop of apartheid South Africa, should now be discussed with more differentiation and greater nuance. Shortly after the inception of a Government for National Unity, the South African Truth and Reconciliation Commission (TRC) was set up to facilitate a process to help South Africans deal with what has happened during apartheid. The TRC was facilitated by the Promotion of National Unity and Reconciliation Act 1995 (Act No 34 of 1995) (Department of Justice and Constitutional Development [DOJ \& CD] 2009), and it was always recognised that this was not a complete process that could include all victims and perpetrators but only the beginning of a process.

Included in the conversation today should definitely be issues of racial reconciliation and on-going healing from past legacies, but now also issues related to class, sexual orientation, xenophobia and inter-generational concerns should be added. The reality of lesbian women being killed in townships or xenophobic attacks that ripped through the soul of the nation in 2008, and sporadically since, need to be dealt with pastorally and publicly.

In preparing for the consultation, other conversations subsequently occurred that helped create a deeper awareness in the CCM (CCM 2011) for its role in the area of reconciliation and healing. The centre started to recognise that the courses for which the demand was biggest were often those dealing with trauma support and trauma counselling. It became clear that this was a raw and topical issue in communities and for pastoral leaders. Institutions working in the fields of reconciliation and healing reached out to us to explore possible partnerships. Individuals from different military veteran organisations requested us to think with them about the creation of safe spaces in which they could tell their stories in order for them to move beyond woundedness to healing and constructive engagement, with each other but also with society at large.

Before I conclude this section, and leading into some of the following paragraphs, it is important to state that the kind of reconciliation proposed in this article is neither the kind that negates or downplays past hurts or the gross nature of past violations nor the kind that lets perpetrators off the hook easily. 'Reconciliation, however, does not mean forgetting or trying to bury the pain of conflict' (Mandela 1995). Such reconciliation is liberating for neither victim nor perpetrator. What is assumed here is reconciliation coupled with restitution, reconciliation resulting from sensitive processes of restorative justice and reconciliation facilitated in the context of difficult issues such as land reform.

Nelson Mandela's definition (1995) of reconciliation as 'working together to correct the legacy of past injustice' speaks of reconciliation as an active and on-going process of collaboration to correct past wrongs. It is much more than superficial, once-off, 'feel good' exercises which do not in any substantive way address the structural injustices or depth of woundedness of the past.

Twenty years into South Africa's democracy, there is a challenge to find new languages of engagement on issues of healing and reconciliation, both to address our collective woundedness as a nation more decisively and in response to the new challenges we face today. It should also focus on redressing on-going structural legacies.

\section{Social cohesion, citizenship and participation}

A next concept to be considered in exploring the possibility of social cohesion is the concept of citizenship and participation. Pope Francis (2013), in his Apostolic Exhortation of 24 November 2013, emphasised this, saying: 'Responsible citizenship is a virtue, and participation in political life is a moral obligation.' The more heterogeneous a society, the more important is a responsible and participating citizenry, truly representing the diversity of a society's members. Forrest and Kearns (2013:2127) ask this question: 'What does citizenship mean in a more multicultural and heterogeneous society ...?'

Active participation by an empowered citizenry at all levels of society would contribute to significantly higher levels of social cohesion and interconnectedness than the myth of social cohesion sometimes perpetuated by public officials, intellectual theorists or branding experts, which does not always hold real substance. The challenge indeed lies in each of those concepts: active, participation, empowered citizenry, all levels of society.

If at the most vulnerable level of society, citizens can be organised, mobilised and empowered to participate fully in determining their own priorities, in accessing resources to address those priorities and in translating their visions into realities. With the support of all relevant institutions, social cohesion can be significantly more than a pipe-dream. If this could result in social cohesion that is fundamentally more than social co-option into the schemes and visions of others, notably government and those who are resource-rich, but occurring with and on the terms of those who are normally excluded from society, social cohesion would become much more than a buzzword. 
If the diverse people inhabiting a city can participate optimally and in meaningful ways in conversation about the future vision of the city and its diverse communities, expressing their own needs and dreams, articulating their assets and resources and participating in the construction and implementation of such a shared vision, a rich mosaic could unfold, much richer than the lofty official visions that often break down at the point of implementation. To illustrate this, imagine a young black South African entrepreneur, a Somali woman trading from her informal shop, a white Afrikaans banker, a homeless person, a child from the inner city and a child from the suburbs, young artists and skateboarders, former struggle activists and former apartheid policemen, teachers from township and upmarket schools, Christian ministers and Muslim imams, activities from the gay and lesbian movements, all sharing their visions and aspirations as citizens of the city, all articulating the ways in which they can contribute to make such visions reality, and then having sensitive designers, planners, and bureaucrats who are able to integrate such diverse visions into one coherent, cohesive vision for the city.

Active citizenship requires an educated and empowered citizenry. Faith communities and churches can play a much more dedicated and informed role to prepare their members to be participating, to be responsible citizens and to understand the practices and possibilities of citizenship. The latter includes legislative frameworks, rights and responsibilities of citizens, opportunities for participation in developmental local government, opportunities for changemaking at a local level, case studies of citizens' movements and citizens' organisations and the power they have to create better and more inclusive futures for all a community's people.

The practice of citizenship needs to be informed and grounded theologically in order to encourage and prepare our members well, articulating it clearly not as something other than our faith but as an expression of our commitment to God's world (cf. Drummond 1893; Hauerwas \& Willimon 1989; Rougeau 2008).

The assumption of the above paragraphs is that inclusive and participative processes, involving all citizens and inhabitants of the city or town - rich and poor, young and old, locals and foreigners, women and men - and truly integrating their aspirations, visions, needs and assets into plans that contribute to the future construction of the city, will go a long way in facilitating a more socially cohesive society.

\section{Social cohesion and social justice}

After the first day of our consultation on social cohesion and reconciliation, it already became clear, to me at least, that any conversation on social cohesion has to start with a conversation on social justice (cf. De Beer 2013a). In other words, a socially cohesive society is a pipe-dream if fundamental issues of social justice, economic equity and the fair distribution of resources are not addressed.
It is important to distinguish between social cohesion facilitated through social control and social cohesion facilitated through social justice. These are two distinctly different approaches to the social-cohesion debate. Where social cohesion or rather a version of cohesion that is smoothing over fault lines or fractures, co-opting socially excluded and violated people into visions of social cohesion that are not fundamentally addressing the injustices against them is prioritised over social justice, it is probably truer to think of it as social control and not as social cohesion. The cohesiveness of such an approach cannot be sustained in the long-run except through excessive policing.

Social cohesion expressed in social control, subduing everybody to the same principles and standards even though the majority are not sharing in the fruit of the land, is a radically different vision from social cohesion measured by the degree to which social justice has been achieved. An emphasis on social justice will hold that a radically restructured society with fair access to sources of livelihood and sustenance is what is required, and is the only thing that will contribute directly to a greater sense of social cohesion.

With reference to street homelessness in England, Fitzpatrick and Jones (2005) makes this point clearly, asserting that measures of social control are taken that coerce or subdue street homeless people in ways that are not promoting their well-being but actually detrimental to it.

A social-justice emphasis in discourses on social cohesion would namely place a higher emphasis on poverty as cause of exclusion and would advocate for a more fundamental redistribution of material resources and of power (equality) as well as equal recognition of and respect for different social groups (diversity) (Fitzpatrick \& Jones 2005:391; cf. Levitas 1998; Young 1990).

In our attempts to facilitate social cohesion, we need to articulate the objectives of social justice, namely redressing injustices, restructuring societal systems and distribution mechanisms and ensuring access to sources of power and livelihood. We also need to ensure that social justice is not co-opted into discourse on social cohesion without real substance and measurable indicators demonstrating the mediation of a more just society at all levels.

\section{Social cohesion and restitution}

During the consultation, it was Deon Snyman (2013) of the Restitution Foundation who emphatically suggested that there can be no reconciliation without restitution. The Restitution Foundation (n.d.) explains its understanding of restitution as follows:

Restitution is a complex term. We typically hear it in a legal sense: a man who has stolen R1000 is ordered to make compensation in the same amount. We often understand it as a quid-pro-quo kind of arrangement: pay back precisely what was taken, and all parties can go their separate ways with the matter resolved. 
We understand restitution to go much deeper than this, and to be one of the most significant tools available to us in addressing the residual ills of apartheid and discrimination as well as other causes of inequity in our communities. Restitution involves seeking to set right the generational ills of inequality by engaging those who have benefited from the system, directly or indirectly, in transferring wealth and social capital and reinvesting in communities that still suffer from the past's grim legacy. (n.p.)

They speak of restitution in the sense of loss of land, education and money (tangibles) but also in terms of the loss of dignity and self-worth (intangibles). They then argue and work for awareness amongst Christians, and others, of their complicity with unjust systems, and they help seek imaginative ways in which people can start to engage and rectify the wrongs of the past. Restitution then becomes a very critical aspect of restorative-justice processes which is not seeking retribution but restoration, not revenge but healing, not superficiality but depth of repair.

A socially cohesive society could not become a reality without deep processes of restitution. It is precisely because of histories of exploitation and loss that we live in a deeply divided society. Without deep acts of restitution, social cohesion would deny the pain and loss of generations of people, pretending to be a society that is together even though it is still deeply fractured and inherently scarred.

The possibilities for restitution are endless. It can be mediated in the one-to-one engagements between people who have wronged and been wronged. It could be a quid pro quo rectification as indicated above, but it could also happen in the many areas where people who have benefited from unjust systems work tirelessly to rebuild a society that is radically inclusive, socially just and economically viable. It could happen where retired school principals and teachers of formerly white schools invest their time and capacity in schools with meagre resources in poor areas or where medical professionals give themselves to communities lacking access to basic and decent health care. It could happen where farmers allow labourers to become shareholders in new agricultural enterprises, backed up by proper training and resources or where building professionals and private developers invest their time voluntarily to facilitate housing with those who are normally excluded from secure tenure and decent accommodation.

All such actions can form part of a ground-swell of people actively participating in acts of restitution and restoration in order to ensure a socially cohesive society.

\section{Social cohesion and land restitution or redistribution}

A key area in which restitution needs not only be theorised about but practiced in concrete, creative and bold ways is the area of land and land redistribution and distribution.

Just as restitution was mentioned as a prerequisite for social cohesion, different voices at the consultation articulated the challenge of land and how it will be addressed, or not, as critical for achieving or working against social cohesion.

In the South African context, millions of people have been dispossessed through apartheid legislation, moved from ancestral land or displaced through the Group Areas Act that determined where people from different races could live and where not. The deep wounds of such displacements are still lurking deep in the collective soul of the nation, but they are also still evident in the spatial patterns of our cities and towns. It is still an unresolved issue 20 years after the emergence of a democratic dispensation, and understandably so because 300 or more years of colonisation and almost 50 years of apartheid cannot be undone overnight. However, if not dealt with constructively, creatively and decisively, it could be like a time-bomb ticking away until it bursts into explosion and undo much of what has occurred in the first 20 years of our fragile democracy.

A distinction needs to be made between land restitution, which is the process of reclaiming land that was lost through apartheid legislation, and land redistribution, which is a political and administrative process of ensuring land is made available in a more equitable way to people from previously excluded groups (cf. Du Preez 2014; Mabasa 2014). Both processes together, in tandem, are required to be implemented effectively, in partnership with and depending on the support of all stakeholders.

These are very delicate processes, and both commercial farmers and government bureaucracy have often been slow in ensuring an adequate redress of the past. If commercial farmers were more committed to social justice and restitution, if they understood that their land ownership is the fruit of centuries of dispossession and if they would then voluntarily participate in land reform, in land sharing programmes and in the empowerment of new land owners or emerging farmers, the process could have developed much further. If government processes were more efficient and expedient, it could also have advanced land restitution and land redistribution way beyond what is currently the case.

A comprehensive social-cohesion strategy needs to include an effective way to ensure land restitution and land redistribution that is expedient, successful and sustainable for current and future generations of people.

The South African church needs to be honest about its complicity in perpetuating injustices in relation to land distribution - both in terms of its theology and its practices. The disparities created are still evident in the church community and not any different from society at large.

\section{Social cohesion and spatial transformation}

The challenge of social cohesion is nowhere more visibly expressed than in the spatial design of cities or neighbourhoods (cf. Deffner \& Hoerning 2011). In South African cities, apartheid planning deliberately ensured the 
social segregation of people according to race, and often land use was also very fragmented, segregating work from leisure and residence instead of promoting integrated communities.

Without a clear strategy of spatial transformation that would, at one level, address the dual processes of proliferating security villages and mushrooming informal settlements and, at another level, work proactively to ensure mixed-use and mixed-income neighbourhoods that serve as 'connectors' or 'bridges' and mend the fractures of cities and towns, social cohesion will remain a buzzword, and only some would be truly included.

City parks like Magnolia Dell in Pretoria or shopping malls in suburban areas often become spaces that mediate social exchange, almost by default. This is not adequately achieved by urban spatial design in South African cities. It is Magnolia Dell that is a 'bridging zone' between the (largely white) suburbs and the (largely black) inner city. Many white suburbanites will not feel at home in and seldom visit the inner city of Pretoria. They do however frequent Magnolia Dell as a 'safe space'. The right kind of design and planning can build on small models such as this one to facilitate 'bridging zones' and, more boldly, 'bridging neighbourhoods' that could help work towards social cohesion in society at large.

In a talk on the soul of the city at a recent gathering on the central square of our city, a woman spoke of her dream to see a pedestrian and/or cycling route, connecting the urban township and informal settlements of Mamelodi with the security villages of the eastern suburbs of Pretoria all along Solomon Mahlangu Road. Such an innovative spatial design feature, connecting formerly included and excluded communities in ways that facilitate mobility, exchange and play, could assist in breaking down walls, in mending fractures and in facilitating social exchange if coupled with many of the other processes outlined above.

The story of Medellín, Colombia, is telling (Cerda et al. 2012; Colby 2013; Drissen 2012; Geisinger 2013; Wilter 2013). A bold plan by non-conformist mayor, Sergio Fajardo, initially sparked a process that resulted in the upgrade of slum neighbourhoods, the creation of an elevated rail link and other creative connecting spaces between poor and rich neighbourhoods. It included developing and upgrading accessible and friendly public spaces and doing all of this in ways that promoted active participation of citizens not only in the creation of the visions and plans but also in the actual implementation and construction of sites. Medellín facilitated spatial transformation in ways that simultaneously developed local social capital and fostered an active sense of citizens' participation. Research found that the homicide rate dropped by $66 \%$ between 2004 and 2008 and the violent crime rate dropped by $74 \%$ in the same period (Cerda et al. 2012)! Spatial transformation facilitated social transformation and a much deeper sense of social cohesion.

\section{Imagining social cohesion: Embracing multiple strategies towards an overarching goal}

At this point, I would like to suggest that, for social cohesion to be imagined as a real possibility, it requires an embrace and intentionality of multiple, parallel strategies ranging from healing and reconciliation to restitution and land distribution and to the spatial transformation of our cities and towns (cf. Figure 1). A singular approach would enable neither the kind of social cohesion that would include and affirm all inhabitants of the city nor the superficiality of social cohesion expressed through political or branding campaigns.

\section{Fostering a practical theological vision or praxis for social cohesion}

In this part of the article, I propose an outline of a practical theological vision or praxis for social cohesion. Practical theology, if regarded as the critical and reflective accompaniment of Christian faith communities in their active participation in God's world, has a definite responsibility (1) to accompany faith communities as they seek to contribute to social cohesion, (2) to assist faith communities in their critical and constructive reflection on social cohesion, (3) to develop an own theological vision for a socially cohesive society, rooted in theological language and aligned to what it would discern to be God's imagination of the world, city or neighbourhood, but also (4) to engage in conversation with a multiplicity of conversation partners (different publics, interdisciplinary, et cetera).

In doing so, faith communities need to be accompanied to reflect intentionally and critically on the challenges of social cohesion but also on their possible vocation and role in

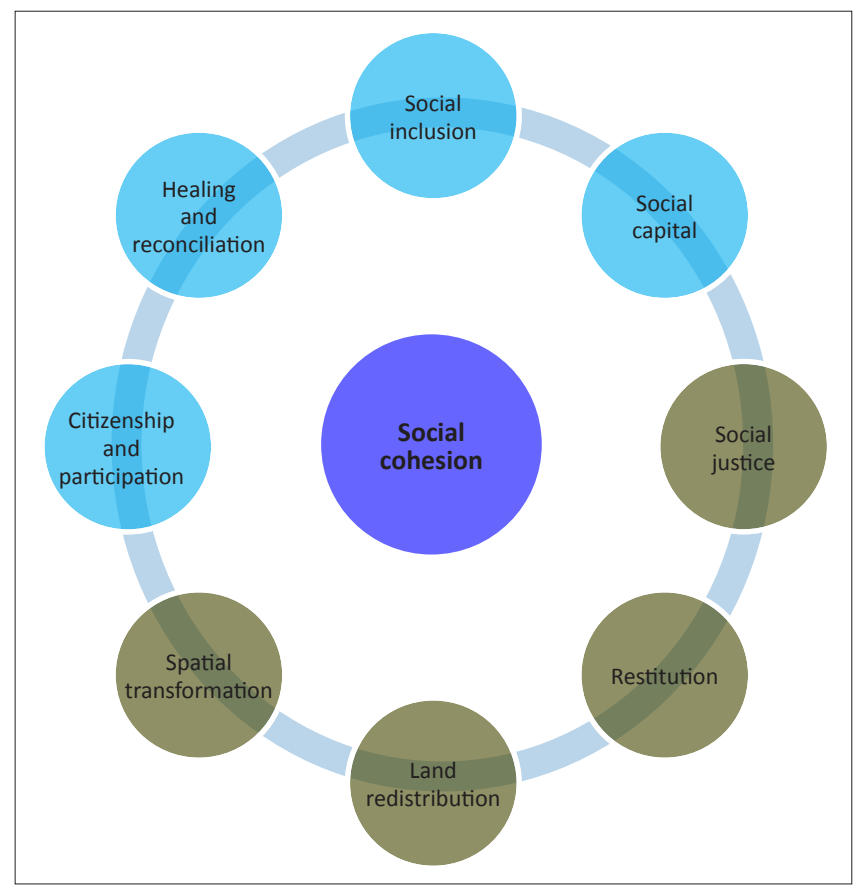

Source: Author's own construction

FIGURE 1: Contributors to social cohesion. 
contributing to the elements discussed in the first part of this article. These include social capital, social inclusion, healing and reconciliation, citizenship and participation, social justice, restitution, land redistribution and spatial transformation and should be considered in order to contribute to a socially cohesive society.

For the sake of this article, I propose seven basic elements as dimensions of a practical-theological vision and praxis for social cohesion: (1) shalom or wholeness, (2) the household (oikos) of God, (3) a spirituality of the table, (4) embodied engagements, (5) deconstructing or constructing multiple narratives, (6) imagining preferred realities and (7) healing fractures in 'the city' and society (cf. Figure 2).

\section{'Shalom' or wholeness}

This proposal suggests that the concept of shalom (wholeness) should be at the core of a practical-theological vision of social cohesion. It is, however, shalom as worked out and imagined from within the realities of deeply fractured and scarred societies, communities, families and individual lives. Shalom is not the same as a false sense of peace or superficial reconciliation. It is a sense of wholeness mediated by concrete expressions of socio-economic-political-generationalenvironmental justice and the healing of generational, collective and individual wounds. In that sense, to work for social cohesion in society, as people of faith, would be to work for an increasingly visible expression of God's shalom (cf. Van Schalkwyk 2000; Linthicum 2006).

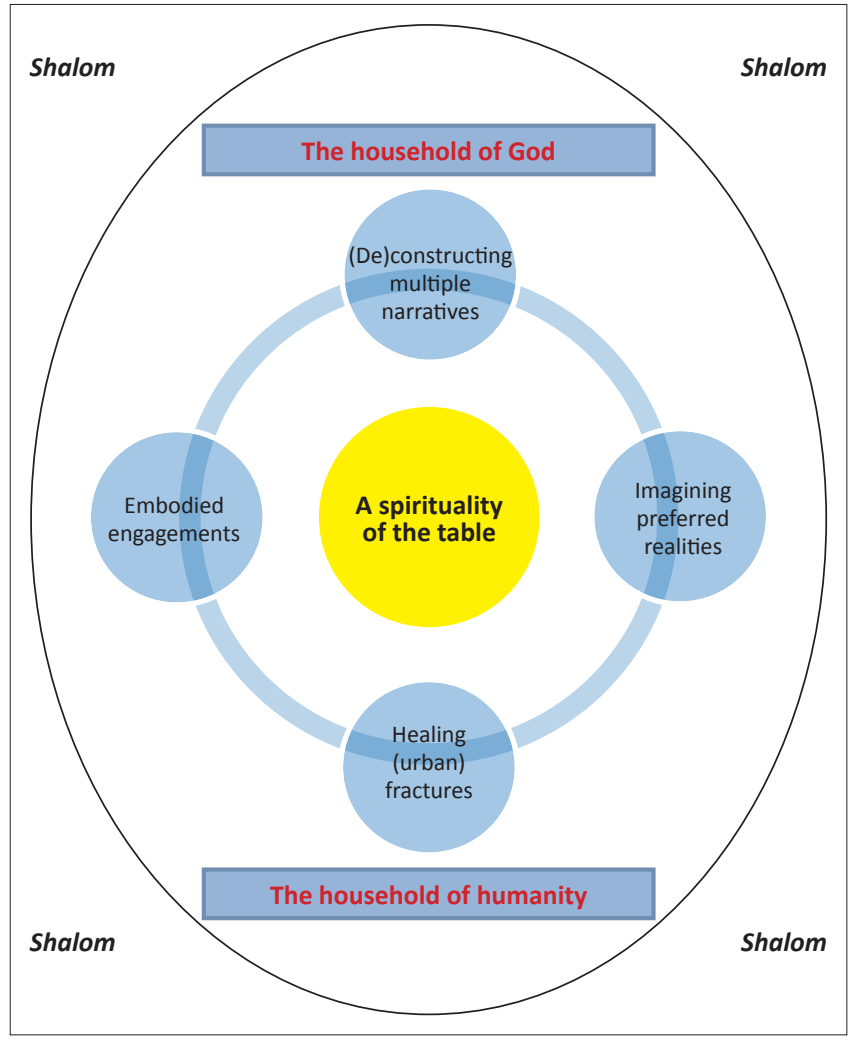

Source: Author's own construction

FIGURE 2: Dimensions of a practical-theological vision for social cohesion.

\section{The household of God}

If shalom is at the core of a practical-theological vision of social cohesion, it is to find its expression in the concreteness of the household of God, namely the household of humanity and the household of all creation. The theological notion of the oikos of God (cf. Diakonia Council of Churches 2006; Span 2010) is already embodying a vision and construct of social cohesion. Social cohesion in a theological sense would be the work of theology and faith communities to make manifest the given that we belong to one, interdependent household of creation. Within that one, interdependent household of humanity, despite our differences, we need to tend carefully to the management of this household, the ways in which resources are shared in this household, the ways in which power is stewarded and inclusion is facilitated, respectfully and fully, to demonstrate wholeness and oneness in the household. Social justice, restitution and land distribution, in such terms, go beyond political rhetoric and become matters of our collective household and its fair management.

Shalom in the household of God is proposed as a possible compelling practical-theological vision to undergird our visions and actions for a socially cohesive society.

\section{A spirituality of the table}

Whereas shalom in the oikos of God always draws us towards the bigger vision, a spirituality of the table can help to earth and root us. It can root us in postures of invitation and inclusivity, of openness and hospitality, of sharing bread and drinking wine, of redistribution and celebration, of play and protest and of dignity and justice (cf. Erlander 2011).

For the faith community, it is at the table of Christ that the many fractures working against a cohesive society will not only surface but will also call us to work for a greater sense of wholeness, both at the table and beyond:

The meal of remembrance in the Christian faith ... is about doing the fragile work of reweaving - sinners and sinned against, victims and perpetrators, wounded and whole, enslaved and free. (De Beer 2013b:n.p.)

This is no spirituality of perfection but indeed of imperfection, inviting the fractures and divisions to the table. It deals with the unfair distribution of resources and animosity amongst sisters and brothers, embracing the messiness of our difference, but allowing the solidarity and fellowship of the table and the mysterious presence of the Spirit to work within and through the fractures, divisions and scars towards healing and unity.

If the table is indeed a place where the faith community is open to the promptings of the Spirit, it needs to be at the heart of a vision for cohesion and wholeness, a vision beyond the fractures and towards wholeness, as Müller (n.d.) says:

Walter Brueggemann described the Christian life as 'telling a past and dreaming a future'. This also suffices as a description of our whole existence. Our stories contain elements of telling 
and dreaming. The greater the gap between the 'telling' and the 'dreaming' becomes, the more the tension will increase, and the more the likelihood of pathological behaviour. On the other hand, where harmony exists between yesterday, today and tomorrow, there will be integrity, wholeness and maturity - the basic ingredients of spirituality. (n.p.)

The table, in the sense of Christian communion, is such a space of 'telling a past and dreaming a future'. It is a constant re-enactment of the Christ story, rooting the community of faith repeatedly in the story of the past whilst imagining a new story for the future. It helps nurture a cohesive story between yesterday, today and tomorrow. It symbolises reconciliation and unity not only with God in a vertical sense but also with sisters, brothers and strangers in a horizontal sense. It announces the possibility of the new community and the ushering in of an era of radical sharing.

\section{Embodied engagements}

Over the past few years, Müller (2011) opted to position his theological work in a post-foundational paradigm. He (Müller 2009:7) suggests that 'concerns in this paradigm are never theoretical, but always local and embodied', connected to real concerns and real persons. A practical-theological vision of social cohesion, if not characterised by embodied engagements with the fractures of society, will at best be impotent.

It is not an arrogant, all-knowing embodiment but one marked by humble listening and a participating presence. It will sit at the table where former soldiers fighting apartheid and former soldiers defending apartheid try to speak to each other. It will engage in processes seeking to bring farmers and farm workers to revisit and to construct and even reimagine their relationship in radically new and refreshingly just ways.

Müller (2009:7) speaks of it as a not-knowing approach, not coming to the table of complexities with any preconceived ideas or pre-packaged answers. Yet, it is an approach of 'active engagement'. Deep listening and a participating presence are signs of such 'active engagement'.

Not only does a practical-theological vision need to be marked by embodied engagements in the fractures and fault lines of society, but it should also accompany faith communities with visions, tools and resources as they seek to move between contexts (racial, economic, generational, et cetera) and across boundaries. 'A postfoundational notion of reality enables us to communicate across boundaries and move transversally from one context to another ...' (Müller 2009:8). In so doing, Müller suggests, we will be enabled to 'find the safe but fragile public space we have been searching for' (Müller 2009:8). Embodied engagement is to be present in fragile situations, not having answers, simply and faithfully seeking to open up safe spaces in which to allow the frailty of difference, exclusion, exploitation and loss to surface and there to deal with it together.

\section{Deconstructing or constructing multiple narratives}

The safe, fragile public spaces Müller speaks of provide the possibility of narrating communities in which the multiple narratives of society can be retrieved, told, engaged with, deconstructed, re-imagined (if need be) and re-storied. The grand narratives of exclusion and exploitation, of injustice and oppression, of both 'victim' and 'perpetrator', need to be invited. Nobody is always and in every narrative victim or perpetrator. Hospitable spaces need to be created that is deliberate about inviting the diversity of the city and society for the sharing of different, sometimes contradictory, narratives because it is in deep listening to diverse stories that insights can be formed, fractures can be understood and bridges of healing can start to surface.

Simultaneously such spaces should be used to invite the socalled tall stories or alternative stories, emerging from within societal fractures: the overcoming of prejudice, innovative land reforms, bold forms of restitution and access to justice and sustainable livelihoods previously not found.

Such deconstructive narratives also need to engage the discourse on social cohesion itself, exploring how official and marginal discourses differ. It should explore how social cohesion is understood differently by government officials, academics, the private sector, community leaders and the poor. It should explore how social cohesion is expressed, or not, in society on a daily basis.

A practical-theological praxis would work tirelessly to create multiple spaces for narratives to be told and retold, drawn towards a vision of shalom or wholeness in the household of God and shaped by the practices of an imperfect table where strangers are invited to become companions and where fractures are invited to be made whole.

\section{Imagining preferred realities}

Müller (2009:8) proposes a social-constructionist approach in which people develop or construct their own preferred realities in ways that make sense to them. As part of a practicaltheological praxis, multiple narratives - also narratives about social cohesion itself - should be deconstructed, but a practical theological praxis should also seek to go beyond these. It should seek to be very intentional about creating spaces in which diverse people, particularly also those who are often not given voice, can participate in imagining and constructing the preferred realities for society. It should not only articulate that which prevents social cohesion but also that which would in a very real and deep way foster cohesiveness that is authentic and not artificial, deep and not superficial, just and not mere rhetoric. In the process of articulating clearly imagined preferred realities, and in taking steps together to concretise such realities, local communities will start to embody a kind of cohesion that transcends all kinds of boundaries. 


\section{Healing (urban) fractures}

A practical-theological praxis rooted in a spirituality of the table and drawn by a picture of shalom or wholeness in the household of God will not only find ways to be present within the fractures of society, but it will always seek for innovative ways to mend, heal or bind together the fractures.

Fuchs (1993) speaks of God's people as instruments of healing in society. Cox (1965:114-125) suggests that the task of the church in the city is precisely 'the healing of urban fractures'. It is in relation to urban poverty that Forrest and Kearns (2013:2126) write: 'The problems of cities and particularly the problems of poor people in poor neighbourhoods in cities are at the heart of current concerns about societal cohesion.'

Although Müller himself is not particularly fond of the term 'healing', finding it too modernistic or instrumentalist perhaps (in borrowing from the medical sciences), the concept of healing belongs to Biblical language and vision, and, if seen as a verb - as the on-going work of seeking to facilitate healing where there is brokenness, to mend where things are torn apart, to create bridges where there is separation and isolation - I would propose a reclamation of healing as central to the task of a practical-theological praxis concerned with social cohesion. However, I then have in mind healing in much more than an individualistic, personal sense (although that too), including also a deep engagement with societal and collective fractures. I have in mind healing not as a final product but as an on-going, embodied and engaged process. Such a public pastoral praxis is what is required of practical theology in a society marked by deep rifts.

\section{A humble privilege}

In closing this article, I would like to ask the following question. Do we even have a right, as theologians and people of faith, to consider contributing towards social cohesion, having ourselves so often modelled and even theologically justified, significantly, the construction of a segregated and fractured society?

Nothing gives us such a right. However, it is at the table that we are invited to participate in overcoming fractures, humbly, as a deep privilege and a clear theological imperative, first in our own midst and then in the world in which we seek to serve.

In the repetitiveness of the table:

- we are repeatedly invited to a humble posture spiritually, personally, collectively, institutionally and theologically - of confessing our own part in creating, fostering and perpetuating a 'proximity of distance' (Forrest and Kearns 2013:2135-2136; Wilton 1998:178) resulting in deep societal fractures

- we are simultaneously invited to eat and drink the grace of Christ in our midst - a grace at work in 'safe but fragile ... spaces'
- we are invited to recommit ourselves constantly to 'patch back together communities unravelling' (Labonte 2004:16), both at a local level but also regionally and globally.

If social cohesion, in a theological sense, is seen as the work of mediating signs of the shalom of God in the oikos of God - affirming our interconnectedness and interdependence in concrete ways in how our society is structured - it is indeed a vision to live for, an essential vocation for the church and a critical contribution to healing societal fractures.

\section{Conclusion}

This article explored social cohesion as a current topical issue, bringing it into conversation with eight interrelated categories. It also sought to present a practical theological vision and praxis for social cohesion. Further research should be done on how these categories relate to each other, or not, how they often compete and how local communities of faith can be accompanied in a practical theological way to foster social cohesion in communities.

\section{Acknowledgements Competing interests}

The author declares that he has no financial or personal relationship(s) that may have inappropriately influenced him in writing this article.

\section{References}

Bernard, P., 1999, 'Social cohesion: A critique', CPRN Discussion paper no F09, Canadian Policy Research Networks, Ottawa.

Centre for Contextual Ministry (CCM), 2011, Unit for social cohesion and reconciliation, viewed 14 January 2014, from http://www.ccm.up.ac.za

Cerda, M., Morenoff, J.D., Hansen, B.B., Tessari Hicks, K.J., Duque, F., Restrepo, A. et al. 2012, 'Reducing violence by transforming neighbourhoods: A natural experiment in Medellin, Colombia', American Journal of Epidemiology April, 2. http://dx.doi. org/10.1093/aje/kwr428

Cloete, P. \& Kotze, F., 2009, 'Concept paper on social cohesion / inclusion in local integrated development plans', final draft, 06 July 2009, Department of Social Development, Republic of South Africa.

Colby, S., 2013, 'The Medellin miracle: Voting out violence and inequality', Saisphere, 27 January, 48-51.

Cox, H., 1965, The secular city: Secularization and urbanization in theological perspective, Collier Books, New York.

Diakonia Council of Churches, 2006, The oikos journey: A theological reflection on the economic crisis in South Africa, Diakonia Council of Churches, Durban.

De Beer, S., 2013a, 'Rainbow: Promise or premise? Consultation on social cohesion and reconciliation', report of a consultation held on 21-22 August 2013, Centre for Contextual Ministry, University of Pretoria.

De Beer, S., 2013b, 'Absence, presence, remembrance: A theological essay on frailty, the university and the city', Verbum et Ecclesia 34(1), Art. \#855, 9 pages. http:// dx.doi.org/10.4102/ve.v34i1.855

Deffner, V. \& Hoerning, J., 2011, 'Fragmentation as a threat to social cohesion?: A conceptual review and an empirical approach to Brazilian cities', paper presented at the International RC21 Conference 2011, Session No.15, Urban Disorder and Social Cohesion, Amsterdam, 07-09 July.

Department of Arts and Culture (DAC), 2012, Social cohesion, viewed 15 January 2014, from http://www.dac.gov.za/social-cohesion

Department of Justice and Constitutional Development (DOJ \& CD), 2009, The TRC report, viewed 15 February 2014, from http://www.justice.gov.za/TRC/report/ index.htm

Drissen, J., 2012, 'The urban transformation of Medellin, Colombia', Architecture in Development, viewed 11 February 2014, from http://www. architectureindevelopment.org

Drummond, H., 1893, The city without a church, Harper, New York. 
Du Preez, M., 2014, 'Land reform: We need honesty', Pretoria News, 21 January 2014, p. 11

Erlander, D., 2011, Manna and mercy. A brief history of God's unfolding promise to mend the entire universe, Fortress Publishers, Augsburg.

Fitzpatrick, S. \& Jones, A., 2005, 'Pursuing social justice or social cohesion? Coercion in street homelessness policies in England', Journal of Social Policy 34(3), 389-406. http://dx.doi.org/10.1017/S0047279405008834

Forrest, R. \& Kearns, A., 2013, 'Social cohesion, social capital and the neighbourhood', Urban Studies 38(12), 2125-2143. http://dx.doi. org/10.1080/00420980120087081

Fuchs, O., 1993, God's people - instruments of healing: Diaconical dimensions of the church, Peter Lang AG, Bern.

Geisinger, J., 2013, Connective spaces and social capital in Medellín, viewed 15 February 2014, from http://archleague.org/2013/03/

Gray, J., 2000, 'Inclusion: A radical critique', in P. Askonas \& A. Stewart (eds.), Social inclusion: Possibilities and tensions, pp. 19-36, Macmillian, Basingstoke.

Hauerwas, S. \& Willimon, W., 1989, Resident aliens: Life in the Christian colony, Abingdon Press, Nashville.

Institute for the healing of memories, 2011, About the institute for the healing of memories, viewed 15 January 2014, from http://www.healing-memories.org

Jenson, J., 1998, 'Mapping social cohesion: The state of Canadian research', CPRN Discussion paper NO F 03, Canadian Policy Research Networks, Ottawa.

Klein, C., 2013, 'Social capital or social cohesion: What matters for subjective wellbeing?', Social Indicators Research 110(3), 891-911. http://dx.doi.org/10.1007/ s11205-011-9963-x

Labonte, R., 2004, 'Social inclusion/exclusion: Dancing the dialectic', Health Promotion International 19(1), 115-121. http://dx.doi.org/10.1093/heapro/ dah112

Lapsley, M., 2013, Stories of Reconciliation, Unpublished Presentation at a Consultation on Social Cohesion and Reconciliation, 21-22 August 2013, Centre for Contextual Ministry, University of Pretoria, Pretoria.

Levitas, R., 1998, The inclusive society: Social exclusion and new labour, Macmillan, Basingstoke. http://dx.doi.org/10.1057/9780230372528

Linthicum, R., 2006, Building a people of power: Equipping churches to transform their communities, Authentic Press, in cooperation with World Vision Press, Waynesboro.

Lister, R., 2000, 'Strategies for social inclusion: Promoting social cohesion or social justice?', in P. Askonas \& A. Steward (eds.), Social inclusion: Possibilities and tensions, Houndmills, pp. 37-54, Hampshire, Basingstoke; Palgrave Macmillan, New York.

Mabasa, B., 2014, 'The landscape of the land restitution programme in South Africa: A closer look beyond the statistics', viewed 11 March 2014, from http://www. polity.org.za

Makhubu, N., 2014, 'ANCYL leaves mourning hawkers in lurch', Pretoria News, 20 January, p. 1.
Maseng, K., 2013, 'Joburg clean sweep leaves traders in the lurch', Fourways Review, 06 November, p. 1.

Mandela, N., 1995, Message by President Nelson Mandela on National Reconciliation Day, posted 16 December 1995, viewed 15 February 2014, from http://www.anc. org.za/show.php?id=3646

Müller, J., n.d., 'Spirituality and the narrative', paper delivered to the Nationa Congress of the Pastoral Association of Pastoral Work, viewed 11 February 2014, from www.julianmuller.co.za

Müller, J., 2009, 'Practical theology: A safe but fragile space', unpublished paper presented at the Joint Conference of Academic Societies in the fields of religion and theology, 23 June, University of Stellenbosch, Stellenbosch.

Müller, J., 2011, 'Postfoundational practical theology for a time of transition', HTS Teologiese Studies/Theological Studies 67(1), Art. \#837, 5 pages. http://dx.doi. org/10.4102/hts.v67i1.837

Nyar, A., 2013, Social cohesion: A critical reflection, viewed 15 February 2014, from http://www.reconciliationbarometer.org.za

Pope Francis, 2013, Apostolic exhortation Evangelii Gaudium of the Holy Father Francis to the bishops, clergy, consecrated persons and the lay faithful on the proclamation of the gospel in today's world, posted 24 November, viewed 15 February 2014, from http://www.vatican.va

Putnam, R.D., 1993, Making democracy work: Civic traditions in modern Italy Princeton University Press, Princeton.

Putnam, R.D., 2000, Bowling alone: The collapse and revival of American community, Simon \& Schuster, New York.

Rougeau, V., 2008, Christians and the American empire: Faith and citizenship in the new world order, Oxford University Press, Oxford. http://dx.doi.org/10.1093/acpr of:0so/9780195188097.001.0001

Snyman, D., 2013, 'Stories of reconciliation', paper presented at a Consultation on Social Cohesion and Reconciliation, 21-22 August 2013, Centre for Contextual Ministry, University of Pretoria, Pretoria.

Span, J., 2010, 'Towards a Biblical theology of "oikos"', St.Francis Magazine 6(February), 1.

The Restitution Foundation, n.d., What is restitution?, viewed 11 February 2014, from http://www.restitutionfoundation.org.za

Van Schalkwyk, A., 2000, 'Sister we bleed and we sing: Women's stories, Christian mission and shalom in South Africa', PhD thesis, Department of Missiology, University of South Africa, Pretoria.

Venter, Z., 2014, 'Tshwane warned about squatters', Pretoria News, 02 January, p. 1.

Wilter, M., 2013, 'Medellin, Colombia: Why inclusivity and innovation are sparking urban renewal (Part 1)', in All, Architecture, Around the World, Community, Economy, Public Space, blog posted on 29 April 2013.

Wilton, R.D., 1998, 'The constitution of difference: Space and psyche in landscapes of exclusion', Geoforum 29, 173-185. http://dx.doi.org/10.1016/S00167185(98)00005-0

Young, I.M., 1990, Justice and the politics of difference, Princeton University Press, Princeton. 